\title{
O que a pesquisa latino-americana de comunicação deve ao Brasil: Relato pessoal de uma experiência intercultural ${ }^{1}$
}

What Latin American communication research owes to Brazil; Personal account of an intercultural experience

\author{
- JESÚs MARTÍN-BARBEROa \\ Pontificia Universidad Javeriana de Bogotá, Facultad de Comunicación y Lenguaje. \\ Bogotá, Distrito Capital, Colômbia
}

\section{RESUMO}

Neste texto, Jesús Martín-Barbero descreve pontos que aproximaram o Brasil de seu pensamento e contribuições brasileiras à pesquisa de comunicação latino-americana. Algumas das dimensões discutidas são: o aporte reflexivo para a compreensão do cenário político-cultural da comunicação, que permitiu pensar como a indústria cultural promoveu uma nova ideia de nação; um entendimento mais complexo, superando a razão dualista, das relações entre o popular e o massivo, que se expressou no país em duas linhas de investigação, a da contra-hegemonia comunicativa e a da competência do sujeito receptor, e também a contribuição das reflexões de autores brasileiros para a discussão dos processos de globalização contemporâneos.

Palavras-chave: Pesquisa de comunicação, teoria da comunicação, Brasil, América Latina, Jesús Martín-Barbero

\section{ABSTRACT}

In this text, Jesús Martín-Barbero describes points that brought Brazil closer to his thought, besides contributions to Latin American communication research. Some of the dimensions discussed are the following: the reflective contribution to understanding the communication political-cultural scenario, which allowed thinking about how the cultural industry promoted a new idea of nation; a more complex understanding, which overcomes dualistic reason, of the relations between the popular and the massive, expressed in the country in two lines of investigation, one related to communicative counterhegemony and the other to the competence of the receiver, and also the contribution of Brazilian authors' reflection to the discussion about contemporary globalization processes.

Keywords: Communication research, communication theory, Brazil, Latin America, Jesús Martín-Barbero 
Quem escreve sobre a sociedade sem querer perder de vista as relações sociais e seus paradoxos não pode construir casamatas mas cabanas, barracos e choças. Moradas feitas de grandes espaços abertos, destinadas à boa comida e à nobre cerveja com os amigos, dentro daquelas conversações onde se ama o que se fala e se desculpa toda a veemência que acompanha uma eventual descoberta de algum aspecto da sociedade e da cultura onde vive.... E nós já sabemos que no caso do Brasil temos uma casa complicada, onde estilos aparentemente singulares e até mesmo mutuamente exclusivos parecem conviver em íntima relação.

-Roberto DaMatta, A Casa e a Rua

\section{INTRODUÇÃO}

$\mathrm{D}$

EVO COMEÇAR MINHA apresentação contando um fato que está tanto na origem da minha aproximação ao estudo da comunicação, quanto no início da sedução que o Brasil tem exercido sobre o meu pensamento. É, pois, a experiência do meu diálogo com esse país, no que diz respeito à pesquisa de comunicação, que vou expor aqui.

Como aluno de Paul Ricoeur em um curso sobre semântica da ação, em 1970, meu trabalho final foi um pequeno ensaio sobre o modo como a pedagogia de Paulo Freire conseguiu transformar a perspectiva fenomenológica em uma pragmática que, convergindo sobre a capacidade performativa da linguagem, no sentido compreendido por Austin (1970), incorporou a análise da ação da linguagem em um programa de ação no qual a alfabetização de adultos, o aprendizado da língua, se convertia em um processo de libertação da própria palavra.

Minhas incipientes notas interessavam a Ricoeur - que ainda não tinha lido Freire - e constituíam a base da minha tese de doutorado, como o título, La Palabra y la Acción (Martin-Barbero, 1972), claramente atesta, bem como a introdução, que, entre filosófica e poética, incorporava o pensamento de Freire desta forma:

A palavra explicita a consciência que vem da ação e, quando questionada, perfura a espessura maciça da situação, quebra o encanto da passividade diante da opressão. Se a palavra sozinha é impotente, a ação só é estéril. A imagem do futuro é engendrada entre as duas. A palavra desenha a utopia que as mãos constroem, e o pedaço de terra liberada torna o poema verdadeiro. (Martin-Barbero, 1972, p. 3)

O programa de Freire (1969) continha para mim a primeira proposta de uma teoria da comunicação latino-americana: porque é ao se tornar uma indagação 
que a palavra instaura o espaço de comunicação e, invertendo o processo de alienação que modifica a palavra reificada, as palavras geradoras refazem o tecido social da linguagem, possibilitando o encontro do homem com seu mundo e com o dos outros; e superando a inércia da linguagem a palavra do sujeito se revela carregada de sentidos e história (pp. 111-133).

Hoje posso afirmar que grande parte do meu próprio programa de trabalho no campo acadêmico da comunicação - pensar a comunicação a partir da cultura - já estava esboçado aí. Continha as principais pistas que desenvolvi ao longo dos anos de 1970 e que apresentei no México em 1978, no que constituiu o primeiro encontro de acadêmicos e faculdades de comunicação na América Latina, organizado por Hector Schmucler na Universidad Autónoma Metropolitana, Xochimilco (UAM Xochimilco).

Nessa apresentação, ousei inverter o sentido da ideia, já quase slogan, que hegemonizava a visão crítica - "a comunicação como processo de dominação" para, misturando Freire com Gramsci, propor o estudo da dominação como processo de comunicação. Partia da análise de Freire (1970) da opressão internalizada pelas sociedades latino-americanas quando "o oprimido viu no opressor seu testemunho de homem" (p. 42). E inseria essa perspectiva na concepção gramsciana da hegemonia como um "processo vivido" (Gramsci, 1977, p. 329), feito não só de forças, mas de sentido. Entender a comunicação, assim, implicava investigar não só os truques do dominador, mas também aquilo que nos dominados trabalha em favor do dominador, essa é a cumplicidade da parte dele e a sedução que se produz entre os dois. Junto com Gramsci, Freire foi quem me ensinou a pensar na comunicação como um processo social e um campo de batalha cultural.

\section{PENSAR OS MEIOS NA FORMAÇÃO HISTÓRICA DO NACIONAL-POPULAR}

Pensar nas relações entre comunicação e sociedade foi para a América Latina a base a partir da qual enfrentamos o paradigma positivista e o campo de decolagem de nosso próprio trabalho teórico. Desvendar o tecido social dos dispositivos comunicacionais foi o modo de acesso ao seu significado como um enclave de opressão ou emancipação. Mas, em meados dos anos 1980, a relação entre comunicação e sociedade tornou-se o que Mabel Piccini (1987) chamou de "remissão em cadeia às totalidades" (p. 16) - imperialismo, oligarquia, ideologia dominante -, carregada de generalizações sociológicas que nos pouparam da análise dos contextos nacionais e locais. A perspectiva crítica do denuncismo tornou-se mero jargão acadêmico vazio.

Meu encontro com esse país, o Brasil, em setembro de 1983, me aproxima de uma análise crítica da comunicação, na qual pensar sobre os meios implica não 
apenas revelar as condições de propriedade e as tramas de poder, mas também pensar o Brasil: sua complexa formação como país, suas densas e conflitivas miscigenações tanto culturais quanto políticas. Começando pelas ambiguidades de um populismo ${ }^{2}$ que, atravessado pela irrupção das massas populares urbanas, instaura o duplo compromisso do Estado com estas e com as velhas classes que detinham o poder, em um compromisso pelo qual o povo concede legitimidade ao Estado e esse reconhece no povo o sujeito do nacional. Investigar, desse ponto de vista, desde a formação do discurso político, o rádio ou a imprensa, o cinema ou a educação, redirecionaram os eixos do projeto crítico, introduzindo novas questões e cenários, nos quais o que estava em jogo não era apenas a função dos meios, mas também a comunicação entre as classes, e entre estado e povo.

Na compreensão do cenário político-cultural da comunicação, tem desempenhado um papel decisivo "As Ideias Fora do Lugar", texto de Roberto Schwarz (1981) que inaugurou na América Latina o estudo das relações interculturais modernas: ou seja, o modo como esses países se apropriam de discursos e formas políticas, como o liberalismo, que entravam em conflito com uma sociedade ainda escravocrata e não poderiam se apropriar deles sem modificá-la. É por meio desse deslocamento que esses discursos deixam de ser estrangeiros e começam a moldar a vida nacional do país. Além do espaço literário em que o texto de Roberto Schwarz se move, nele se tornam inteligíveis as formas estranhas como as culturas se comunicam, tudo o que há de mal-entendidos, decepções e verdades na comunicação entre os diferentes tempos e mapas mentais contidos nas culturas e como essa interação se mobiliza e complexifica na troca e apropriação de qualquer traço ou elemento cultural.

Acredito que essa perspectiva inovadora foi possível no Brasil pela densidade com que têm sido pensadas as contradições históricas de sua formação como nação e, portanto, a trama de cumplicidades e seduções de que sua cultura nacional é feita. Esse é o debate brasileiro sobre a cultura nacional-popular. Essa que Mario de Andrade vislumbrou em seu projeto nacionalista de "sintetizar e estabilizar uma expressão musical de base popular, como forma de conquistar uma linguagem que concilia o país na horizontalidade do território e na verticalidade das classes" (Squeff \& Wisnik, 1983, p. 148), mas que, no início dos anos 1980, é vista por Adauto Novaes como uma expressão de um ideal sem realidade objetiva, que, no entanto,

transforma a multiplicidade de desejos das diversas culturas em um único desejo: o de participar do sentimento nacional. Operação diabólica e eficiente que faz com que o desejo não caia em um objeto real - a própria cultura - mas em um sentimento externo e abstrato. (Novaes, 1983, p. 8) 
Esse debate me parece crucial para os estudos de comunicação, e com exceção do México, nenhum outro país tem tido a densidade teórica e política do Brasil. Um bom resumo do que esse debate mobiliza são os seminários coordenados por Marilena Chaui $(1983,1990)$. Após rever os diferentes manifestos e momentos do debate, Chaui (1983) propõe três abordagens: 1) a do nacional e do popular como "um campo de significados e práticas, teóricas, empíricas, imaginárias e simbólicas, em cujo interior aprendemos a articular a política, a cultura e a história" (p. 55); 2) em um segundo momento, assinala o dilema que até hoje continua a dividir a pesquisa: a busca que visa descobrir manifestações em si do nacional-popular ou a indagação em algumas áreas da produção cultural dos modos e formas como o nacional e o popular são representados; 3 ) finalmente, aborda a imbricação do nacional-popular nas produções da indústria cultural, e isso em três níveis: como retrato do cotidiano, ou seja, a forma como as pessoas comuns vivem, como revalorização crítica da vida cotidiana e seus valores e como democratização cultural que torna possível a presença do povo na televisão, obviamente submetido às exigências desse novo populismo que mobiliza o mercado, impondo como características a centralização e a heteronomia.

Duas das investigações mais lúcidas, nas quais se percebe empiricamente o enriquecimento introduzido por essa perspectiva, são aquelas realizadas pelo Squeff e Wisnik (1983), na música, e por Ramos (1983), no cinema. Na primeira, é traçado o caminho que, partindo da fazenda de escravocrata, permite a chegada da música negra à cidade. Desprezada como obscena pelas elites e reduzida ao folclore pelos populistas, a música negra entra na cidade pela mão de dois atores vistos como cultural e ideologicamente perigosos: a do mercado de rádio e disco, e a da vanguarda estrangeirizante. Sua incorporação à cidade gerará uma nova cultura, "que se realiza por apropriações polimorfas e pelo estabelecimento de um mercado musical onde o popular em transformação convive com elementos da música internacional e da cotidiana cidadâ" (Squeff \& Wisnik, 1983, p. 148). O gesto negro torna-se popular-massivo, ou seja, campo contraditório de afirmação do trabalho e do lazer, do sexo, do religioso e do político. Um circuito de idas e vindas, de entrelaçamentos e sobreposições conduz à passagem que a partir do candomblé leva essa música ao disco e ao rádio. É o circuito de estratagemas e astúcias, de táticas, no sentido dado a elas por Michel de Certeau (1980, p. 21), de que é feita a luta dos dominados para abrir seu caminho ao reconhecimento social.

Na pesquisa de Ramos (1983) sobre cinema, também testemunhamos o traçado de um trajeto explicitamente ligado às evoluções do nacionalismo estatal e à consequente politização de um cinema que busca explicar a realidade/identidade brasileira, seja através de um "cinema de conscientização" (à 
Diegues) ou de um "cinema antropológico" (à Glauber Rocha). O que acontecerá é uma relação perversa entre estado ditatorial e crescimento da indústria cinematográfica. A modernização orientada pelo Estado dará origem a uma Política Nacional de Cultura (1975) em que "conceituada a cultura como uma questão de nacionalidade", ela será disputada pela tendência estatal de transformar o cinema em um "aparato de hegemonia" e pela busca da construção de uma identidade nacional-popular, que, por sua vez, se tornará um terreno estratégico de disputas entre a visão totalizadora do "nacionalismo defensivo" (p. 199) - de certas esquerdas e de todas as direitas diante da busca por um cinema independente que faça emergir a diversidade cultural do país: a multiplicidade de manifestações da cultura popular diante da unificação estatal ou da homogeneização do mercado.

Em 1988, Renato Ortiz, que já havia dedicado um livro a explorar as aventuras e ambivalências das ideias sobre cultura popular e identidade nacional no Brasil (Ortiz, 1985), recoloca essa discussão - "sempre foi entre nós uma forma de se tomar consciência de nosso destino, o que fez com que ela estivesse intimamente associada à temática do nacional e do popular" (Ortiz, 1988, p. 7) - no processo de emergência e formação da moderna indústria cultural. O chocante já está no título do livro, A Moderna Tradição Brasileira, e desde suas primeiras páginas - em que chama a atenção para o silêncio a respeito da questão da cultura de massa entre a maioria dos intelectuais, cujos preconceitos sobre o rádio ou a televisão os impediram de perceber a consolidação de uma cultura de mercado "que cresceu sob seus pés" - até as últimas, nas quais cunha a categoria do "internacional-popular". Nesse trecho Ortiz (1988) percebe uma série de fenômenos que trazem à tona as peculiaridades brasileiras da indústria cultural.

Desde os anos 1950, alguns escritores, diretores e críticos de teatro começam a perceber que no Brasil, "contrariamente aos países centrais, a dramaturgia do palco se associa a uma tecnologia de massa: a televisão ... [, permitindo] um trânsito entre esferas regidas por lógicas diferentes" (p. 29). Em outras palavras, abre novos espaços de criação para alguns grupos culturais, ao mesmo tempo que atrai certos intelectuais para atuar dentro da lógica comercial. Esse trânsito brasileiro entre lógicas diferentes e até mesmo contrárias tem a ver com uma modernidade cujo significado também é fora de lugar e se torna especialmente claro no desencaixe entre a modernidade estética de seu cinema (ou sua arquitetura) e as condições materiais de seu surgimento. Esse silêncio sobre a cultura de massa "cede lugar a uma fala que articula modernização e indústria cultural" (p. 37).

O melhor exemplo da nova ideia de nação que a indústria cultural promove será a televisão como veículo de integração nacional. É aí que as particularidades do local são definitivamente superadas por uma modernização que finalmente 
integra os mercados regionais em um único mercado nacional: a comunidade dos consumidores é agora a base da nova identidade nacional, da qual a novela é o melhor discurso. Mas, como Walter Durst observa, a telenovela apresentava para o Brasil uma dupla contradição: veio de fora, da Argentina, e também era pura alienação: "Isso explica nosso nariz empinado quando dizíamos: puxa vida, em não fazer novela. Nós que já tínhamos conquistado, saído da alienação para chegar numa realidade brasileira, e de repente, voltou tudo pra trás" (Durst, citado por Ortiz, 1988, p. 177). Mas talvez nem tanto; para Roberto DaMatta (1985) a telenovela é, pelo contrário, a forma extrema do gênero brasileiro por excelência, o carnavalesco: esse "em que autor, leitor e personagens trocam constantemente suas posições” (p. 96). Carnavalização que encontrará sua plenitude quando, convertida em indústria cultural de ponta, a telenovela brasileira $^{3}$ - de A Escrava Isaura a Roque Santeiro - substitui sua capacidade de dizer o nacional no discurso em um segundo momento de sua modernidade: o do internacional-popular.

Acredito que essa perspectiva brasileira, que envolve a investigação do sentido dos meios massivos na compreensão das transformações do país, vai muito além do espaço acadêmico e nos insere diretamente na política. Não poderia ser mais significativo do que é no Brasil, onde a televisão é talvez mais fortemente mediada pelas condições de mercado até se constituir em uma indústria gigantesca, na qual esse meio se tornou um espaço de cruzamentos estratégicos com sua tradição cultural, teatral, novelesca, cinematográfica e mesmo com o pensamento e a obra de não poucos intelectuais e artistas de esquerda. Enquanto na maioria dos países da América Latina os intelectuais e artistas continuam padecendo de um persistente mau olhado que os torna insensíveis aos desafios colocados pelos meios, e em particular pela televisão, no Brasil alguns dos mais importantes filósofos e cientistas sociais, como Décio Pignatari, Sergio Micelli, Muniz Sodré, ou escritores e artistas, como Walter Durst, Dias Gomes, Doc Comparato ou Aguinaldo Silva, são autores de pesquisas e ensaios decisivos sobre as relações da televisão com o país, ou roteiristas e diretores de séries e telenovelas bastante expressivas tanto das mestiçagens e transformações do país quanto de sua capacidade de experimentação dramática e audiovisual.

\section{A CULTURA POPULAR COMO ESPAÇO DE CONTRA-HEGEMONIA COMUNICATIVA}

A outra propriedade que me parece caracterizar como um todo a pesquisa brasileira de comunicação, e que constitui uma segunda contribuição estratégica para a investigação latino-americana, é a precoce superação da razão dualista,
${ }^{3} \mathrm{~A}$ esse respeito ver: Ortiz et al. (1988); Fadul (1993); Busato e Capparelli (1990); Meyer (1996), em especial a segunda parte: “O Folhetim no Brasil". 
essa que tem nos impedido tenazmente de compreender a complexidade das relações entre o popular e o massivo, obstruindo, por sua vez, o desenho de projetos políticos capazes de assumir o que os meios têm de cultura e os diversos usos sociais que as pessoas podem fazer deles.

Foi na precoce e pioneira pesquisa de Sergio Miceli (1972) sobre os programas de auditório na televisão, em que pela primeira vez é formulada uma reflexão teórica que, por um lado, afirma a presença de "demandas simbólicas peculiares, que não coincidem inteiramente com o arbitrário cultural dominante" (p. 210), nos produtos da indústria cultural, e, por outro, questiona uma leitura dos produtos massivos que, ao ignorar e desprezar o sistema de representações e imagens com os quais os setores populares decodificam os produtos simbólicos, acaba assumindo como a única a representação que a cultura dominante oferece de si mesma e do outro. Ao atribuir às mensagens da indústria cultural o status de meros indicadores ideológicos, o pesquisador coloca como pressuposto, ou já resolvido, o que deve constituir o problema a ser investigado: qual é a posição efetiva que a indústria cultural ocupa em um mercado material e simbólico não unificado, ou seja, no qual se cruzam produtos, demandas e leituras heterogêneas?

Em um de seus ensaios mais recentes e expressivos, "Antropologia da Saudade", Roberto DaMatta (1993) fala de uma antropologia capaz de pensar junto o que esse "conceito duplo" - saudade - tem de experiência de passo, de passagem e duração, experiência de um tempo pensando a partir de dentro, e dessa outra temporalidade que é a uniforme e abstrata, cronométrica e progressiva. Porque a saudade - "essa emoção que os brasileiros aprendemos a sentir como aprendemos a brincar carnaval e a comer feijoada" (p. 23) - é uma categoria relacional de tempo, ao mesmo tempo universal e marcada por uma forma peculiar de lidar com a duração: a de uma memória cuja experiência de tempo coletivo indica retornos, reversões, recursividades cíclicas. Assim, até mesmo a temporalidade englobada pelo mercado é atravessada por uma duração vivida, esteticamente apreendida. Essa é a mesma concepção que, dez anos antes, DaMatta (1985) havia colocado para entender as relações entre a casa e a rua:

o básico é estudar aquele " $\&$ " que liga a casa-grande com a senzala, aquele suposto espaço vazio e medonho, que relaciona dominantes e dominados ... e que é capaz de reunir desejo e lei, liberdade e controle, trabalho e malandragem: sexo e casamento, descoberta e rotina, excesso e restrição, relações pessoais e leis universais, vida e morte, indivíduo e relações. (pp. 21, 106)

Entre essa heterogeneidade não unificada do mercado simbólico, de que fala Miceli, e a temporalidade relacional que para DaMatta constitui a originalidade 
da saudade, estão as chaves de uma concepção não maniqueísta das relações entre cultura popular e indústria cultural que têm permitido o avanço de duas linhas estratégicas de pesquisa no Brasil: a da contra-hegemonia comunicativa e a da competência do sujeito receptor. A primeira é baseada em uma concepção moderna da cultura popular, ou seja, aquela que, em vez de rastrear os traços da pureza original, do autêntico-autóctone, se pergunta, em vez disso, sobre o que continua vivo, de modo que o popular se conecta com o hoje, com os mundos da vida do povo, com suas esperanças e suas lutas. É para isso que as obras pioneiras de Luiz Beltrão (1980) apontam ao investigar a atualidade e a validade das formas de comunicação popular na riqueza cultural de seus festas e discursos, tanto rurais quanto urbanos, religiosos e cívicos, desde os discursos do messianismo até os da política, passando inclusive por grafites eróticos e mesmo pornográficos.

É muito significativo que, do Ciclo II, em 1979 (Melo, 1980), ao Ciclo IV, em 1981 (Silva, 1982), da Sociedade Brasileira de Estudos Interdisciplinares da Comunicação (Intercom) - o de 1980 foi sobre comunicação e populismo -, o eixo temático dado aos pesquisadores tenha sido a comunicação nas classes subalternas e as relações entre hegemonia e contrainformação. No de 1979 há tanto uma desmistificação do popular quanto uma das primeiras leituras críticas na América Latina do elitismo pessimista dos frankfurtianos baseada na leitura de Benjamin, de Swingewood e de Enszenberger, enquanto se desenha um novo mapa dos meios como cenário das lutas pela hegemonia. Em um nível teórico, merece ser destacada uma declaração de Brandão, citado no esplêndido trabalho de Carlos Eduardo Lins da Silva:

Quando as condições de vida são transformadas e as lutas do povo tomam outro rumo, as falas de sua cultura não só mudam, devem mudar. Querer preservá-las somente porque são "do povo" ou da "nossa tradição" é fazer o jogo dos controladores do "popular" transformado em mercadoria de consumo erudito. (Brandão, citado por Silva, 1980, p. 47)

Os objetos de estudo que são esboçados não têm nada de convencionais, pois vão da história das formas de resistência da cultura popular no século XVI, ou a imprensa popular no século XIX, até a música sertaneja, canções de romaria e a literatura de cordel. A concepção brasileira da cultura e da comunicação popular é enriquecida quando, no Ciclo IV (1981), essa problemática é repensada à luz do conceito gramsciano de hegemonia, e da proposta, também nesse momento nativa da Itália, de uma práxis comunicativa de contrainformação. Porém chega-se ao conceito, mais do que por sua riqueza teórica, por uma jornada pela práxis 
da comunicação latino-americana, na qual se destaca o surgimento das rádios mineiras na Bolívia, práxis criada nos sindicados do altiplano por volta do ano de 1950. E é a partir daí que será possível repensar a condição especializada da pesquisa de comunicação para propor uma perspectiva interdisciplinar e um diálogo entre a teoria dos meios e as ciências sociais, com ênfase na teoria política e em questões colocados no âmbito das diversas práticas de comunicação, tanto hegemônicas quanto subalternas (Silva et al., 1982, p. 9).

O conceito de hegemonia, que estava apenas começando a ser trabalhado na América Latina, vai realocar o estudo da comunicação no campo da cultura e, especialmente, da política cultural. Isso permitirá a conexão precoce com a teoria cultural, proposta por Williams, da Escola de Estudos Culturais de Birmingham, e com a reflexão que, a partir de Bolonha, permitiu a Pio Baldelli legitimar o uso social dos meios massivos - do rádio ao teatro, passando pelo cinema e a imprensa - pelas classes subalternas. Ou seja, a inserção dos meios nos projetos políticos de insurreição cultural ou guerrilha semiológica com o objetivo de contrainformar, isto é, colocar em circulação uma informação a serviço dos setores populares, e ao mesmo tempo incentivar a iniciativa cultural e a criatividade popular. A reflexão teórica e o mapa das práticas brasileiras pelas quais passa a contrainformação, em que se constrói uma hegemonia popular - imprensa e teatro dos trabalhadores, cinema documental, literatura popular, práxis comunicativas nas comunidades religiosas de base -, coincidem com o que na Europa se reúne, nesses mesmos anos, no congresso coordenado por José Vidal Beneyto (1979) perto de Barcelona, em cuja introdução ele escreve:

A alternativa é popular ou se degrada em brinquedo e/ou máquina de domínio. E popular significa que possibilita a expressão das aspirações e expectativas coletivas produzidas por e a partir dos grupos sociais de base. Tanto majoritários quanto minoritários. Tanto em nível patente quanto latente. (p. XXXIX)

A criatividade comunicativa das culturas populares encontrará apoio no Brasil, por um lado, na força dos movimentos sociais e sua lucidez em assumir os meios como um palco de luta política e cultural, quando a maioria dos sindicatos e movimentos da América Latina ainda sofria de uma grande miopia instrumental e moralista a esse respeito; e, por outro, na teoria das brechas que as próprias contradições políticas abrem nas indústrias culturais. No que diz respeito à relação entre os movimentos sociais e os meios, o trabalho de Regina Festa e Luiz Fernando Santoro (1991) será crucial: não apenas por sua longa experiência como comunicadores nos grandes sindicatos de São Paulo e sua animação de projetos comunicacionais em diversos movimentos pelo Brasil e 
América Latina, mas também por seu acompanhamento reflexivo dos diversos momentos pelos que o país e os movimentos sociais vêm passando (Festa \& Santoro, 1991; Festa \& Silva, 1986).

A teoria das brechas - que deu não pouca esperança aos latino-americanos nos anos difíceis da repressão ditatorial, que devastou a maioria dos nossos países entre os anos 1970 e meados dos anos 1980 - é gestada no Brasil a partir do encontro entre algumas ciências sociais abertas às transformações da indústria cultural, que eles olham não como "um todo monolítico e impenetrável, instrumento utilizado pelas classes dominantes para impor sua ideologia a toda a população", mas como um espaço "de atividade cultural em que há uma autonomia relativa" (Silva, 1986, p. 31). Esta é expressa nas contradições de conteúdo e sentido que os consumidores lhes dão, com a experiência múltipla das comunidades cristãs de base, e com o jogo da cintura ${ }^{4}$, do futebol à política, que tem permitido aos setores populares driblar o adverso. Referindo-se à cultura negra, Muniz Sodré (1983) nos dá um antecedente fundamental para entender o significado que os brasileiros dão às brechas: são espaços considerados inofensivos, não cumulativos da perspectiva branca, e nos quais "os negros revividos clandestinamente seus ritos, cultivaram seus deuses e retomavam a linha da relação comunitária" (p. 124).

Esse é especialmente o caso do rádio, meio desprezado pelos estratos cultos, justamente por ser o território do oral e, portanto, ele mesmo espaço de experimentações populares, como as apontadas por um grupo de pesquisadores sobre o programa de Gil Gomes ${ }^{5}$, que, diante do discurso do noticiário - com sua ocultação do sujeito narrador e do enredo narrativo -, exalta o narrador, transformando a enunciação, a própria experiência do narrador, em um relato de experiência que torna presente o lado corporal da arte de narrar. Corpo que é voz, que carrega a história com efeitos sensoriais e explora a partir do tom e ritmo - que acelera, desacelera, muda, altera, grita, sussurra - o universo das emoções e a experiência de escuta. E se, como bem assinala Maria Immacolata Vassallo de Lopes (1988), a voz de Gil Gomes "é o testemunho envolvido em sua inserção no poder" (p. 139) e na manutenção da ordem, contudo talvez essa voz não seja inteiramente plana e seja feita de inflexões e dobras que, quando dramatiza o real, dota os personagens anônimos da crônica policial com um rosto, situação e vida cotidiana, e através dessa descrição permite sentir os pobres desenraizados, habitantes da cidade, como pessoas.

Foi no mesmo movimento que resgatava a criatividade comunicativa das culturas populares que pesquisadores brasileiros detectaram a presença da $v o z d o$ ouvinte, a face oculta do sujeito receptor. Ao lado das minhas leituras de Michel de Certeau (1980), bem no início dos anos 1980, tenho que colocar o texto em fotocópia da investigação Sobre a Recepção Crítica dos Meios de Comunicação de
${ }^{4} \mathrm{~A}$ aplicação dessa expressão às táticas da cultura popular é de Alves (1987).

${ }^{5}$ No original, o autor faz aqui uma referência a "VV.AA. A narrativa popular de Gil Gomes. São Paulo, 1984". Tentamos obter os nomes dos autores e da editora, conforme os parâmetros da norma utilizada na revista, mas não tivemos sucesso (N. do E.). 
Massa no Brasil, de Anamaria Fadul (1983), uma investigação, se bem me lembro, encomendada pela União Cristã Brasileira de Comunicação Social (UCBC). Também em fotocópia, recebi o manuscrito de A Rosa Púrpura de Cada Dia: Trajetória de Vida e Cotidiano de Receptores de Telenovela, de Mauro Wilton de Sousa (1986). Se no texto de Anamaria a recepção é explorada principalmente na diversidade de sua capacidade de leitura questionadora das mensagens dos meios massivos, no de Mauro Wilton a investigação já se concentra nas modalidades de inserção da telenovela na vida cotidiana dos jovens trabalhadores.

Penso que, na precoce atenção prestada pelos pesquisadores brasileiros à competência de leitura do receptor e na inserção dela no mundo do cotidiano, tem desempenhado um papel importante a presença pioneira - em relação ao resto da América Latina - de uma antropologia urbana que consegue passar de uma antropologia na cidade para uma antropologia da cidade (Cardoso, 1986), exploradora dos mundos da vida popular, do circo (Magnani, 1984) à cultura política do bairro (Caldeira, 1984), e da cultura da classe média (Velho, 1981) às representações e imaginações dos educadores (Rocha et al., 1984). É justamente uma antropóloga, Ondina Fachel Leal (1990), que sistematicamente introduz o trabalho etnográfico em pesquisa sobre recepção televisiva, o que terá amplo eco em investigações em outros países latino-americanos, especialmente por sua indagação sobre o espaço e o tempo de assistir à telenovela, e a comparação dos processos de leitura, ou seja, da produção e da reformulação simbólica que duas classes sociais de espectadores realizam com a telenovela.

Do ponto de vista sociológico, Carlos Eduardo Lins da Silva (1985) investiga pioneiramente a recepção do noticiário nacional da Rede Globo em duas comunidades da classe trabalhadora, questionando especialmente as mediações críticas que a Igreja, o movimento sindical, os partidos políticos, o movimento feminista e os demais meios de comunicação introduzem na leitura do telejornal. Junto com esses trabalhos pioneiros, não posso deixar de destacar o seminário que um grupo de pesquisadores da Universidade de São Paulo realizou em 1991, do qual participaram sociólogos, antropólogos, comunicadores, psicólogos e historiadores, cujo mero título, Sujeito, o Lado Oculto do Receptor (Sousa, 1995), é muito revelador das peculiaridades que, além da moda acadêmica, caracterizam os estudos de recepção no Brasil.

\section{GLOBALIZAÇÃO COMUNICACIONAL E MODERNIDADE-MUNDO}

Um fantasma percorre as ciências sociais e a pesquisa de comunicação latino-americana nos últimos anos: o fantasma se chama globalização. Confundida por muitos com o velho e persistente imperialismo - assimilado à transnacionalização, 
ou melhor, à expansão acelerada de empresas e lógicas transnacionais - e identificada por outros com a revolução tecnológica e mesmo com o impulso secreto da pós-modernidade, a globalização não parece se deixar capturar por esquemas acadêmicos nem por paradigmas científicos tradicionais. Os artigos e antologias proliferam infinitamente, mas a grande maioria do que está escrito na América Latina a esse respeito decepciona. Curiosamente, é no país que mais ampla e polemicamente tem debatido as vicissitudes de sua formação nacional, o Brasil, que começa a ser traçado um horizonte de compreensão da novidade que os processos de globalização introduzem na economia, na cultura e na sensibilidade, isto é, na percepção de espaço e tempo.

Três brasileiros se destacam hoje como pensadores da globalização na América Latina. A partir da geografia, Milton Santos (1993) reflete sobre as transformações do espaço, afirmando que, devido à falta de categorias analíticas e da história do presente, ainda estamos mentalmente ancorados no tempo das relações internacionais, quando o que precisamos pensar hoje é o mundo: a passagem da internacionalização para a mundialização. São precisamente as tecnologias de comunicação - satélites, informática, televisão - que, ao transformar o sentido de lugar no mundo, tornam opacas as relações que o estruturam, fazendo de um mundo tão interconectado algo opaco. Essa opacidade coloca em primeiro plano a materialidade da qual é feito o espaço e a velocidade que nos torna perceptível um mundo que, na medida em que transforma a cultura no grande veículo da economia e da política, torna-se a chave para a mudança epistemológica que todas as disciplinas sofrem.

No entanto, essa avaliação do mundo não impede Milton Santos (1995) de fazer uma análise fortemente crítica de uma globalização enferma (pp. 22-42), porque busca unificar, mais do que unir, e

o que hoje é unificado em todo o mundo não é um desejo de liberdade, mas de dominação, não é o desejo de cooperação, mas de competição. ... O espaço se globaliza, mas não é mundial como um todo, mas como uma metáfora. A dimensão mundial é o mercado. (Santos, 1995, p. 33)

Há então um relógio universal e abstrato, hegemônico, cujas temporalidades são os vetores da economia e da cultura. Mas não há tempo mundial. $\mathrm{E}$ se é verdade que são as redes mundiais que regulam uma ordem a serviço dos atores hegemônicos em escala planetária, no nível local essas mesmas redes são portadoras de desordem. A indagação a respeito da globalização se torna, assim, uma questão sobre o sentido da diversidade: "A diversificação contribui para a unidade ou a unificação?” (Santos, 1995, p. 41). 
A partir da sociologia, Renato Ortiz (1994) introduz a necessidade de diferenciar as lógicas unificantes da globalização econômica daquelas que mundializam a cultura. Pois a mundialização cultural não funciona de fora, em esferas dotadas de autonomia, como a nacional ou a local. A mundialização é um

processo que se reproduz e se desfaz incessantemente ... Neste sentido seria impróprio falar de uma "cultura-mundo", cujo nível hierárquico se situaria fora e acima das culturas nacionais ou locais.... O processo de mundialização é um fenômeno social total que permeia o conjunto das manifestações culturais. Para existir, ele deve se localizar, enraizar-se nas práticas cotidianas dos homens. (Ortiz, 1994, p. 30)

A mundialização não pode, então, ser confundida com a padronização dos diferentes âmbitos da vida, que foi o produto da industrialização, incluindo o âmbito da cultura, essa indústria cultural que foi objeto de análise dos frankfurtianos. Agora estamos diante de outro tipo de processo, que se expressa na cultura da modernidade-mundo como "uma nova maneira de 'estar no mundo" (Ortiz, 1994, p. 33), que diz respeito às profundas mudanças produzidas no mundo da vida: no trabalho, no casamento, na comida, no lazer. É porque a jornada de trabalho integral tornou impossível para milhões de pessoas almoçarem em casa, e porque a cada dia mais mulheres trabalham fora dela, e porque as crianças se autonomizam dos pais muito cedo, e porque a figura patriarcal tem sido desvalorizada tanto quanto o trabalho das mulheres tem sido valorizado, que a alimentação diária deixou de ser um ritual que reúne a família, e, dessimbolizada, encontrou sua forma no fast food.

Assim, o sucesso do McDonald's ou do Pizza Hut fala menos da imposição da comida estadunidense do que das profundas mudanças na vida cotidiana das pessoas, mudanças que esses produtos, sem dúvida, expressam e monetizam. Dessincronizados dos tempos rituais do passado e dos lugares que simbolizavam o convívio familiar e o respeito à autoridade patriarcal, os novos modos e produtos alimentares "perdem a fixidez dos territórios e dos costumes . . . são informações ajustadas à polissemia dos contextos" (Ortiz, 1994, p. 87) ${ }^{6}$. Reconhecer isso não significa ignorar a crescente monopolização da distribuição, ou a descentralização que concentra o poder e a desenraização empurrando a hibridização das culturas. Estruturalmente ligados à globalização econômica, mas sem se esgotar nela, há fenômenos de mundialização de imaginários ligados a músicas, imagens e personagens que representam estilos e valores desterritorializados aos quais também correspondem novas figuras da memória.

Também a partir da sociologia, Octavio Ianni (1996) tem sido um dos poucos latino-americanos a se atrever a assumir os desafios teóricos envolvidos em pensar 
"que o globo deixou de ser uma figura astronômica para adquirir plenamente um significado histórico" (p. 3). Não se pode derivar essa significação mais do que até agora foi a categoria central nas ciências sociais, a do estado-nação, a globalização não pode ser considerada como mera extensão quantitativa ou qualitativa da sociedade nacional. Não porque essa categoria e essa sociedade não continuem a ter validade - a exasperação dos nacionalismos, dos regionalismos e localismos atesta isso -, mas porque o conhecimento acumulado sobre o nacional responde a um paradigma que não pode mais prestar contas "nem metodológica, nem histórica nem teoricamente a toda a realidade em que indivíduos e classes, nações e nacionalidades, culturas e civilizações estão inseridos hoje" (p. 160). A resistência nas ciências sociais em aceitar que se trata de um novo objeto é muito forte. Daí, por um lado, a tendência de subsumir esse objeto nos paradigmas clássicos do evolucionismo, do funcionalismo etc., e, por outro, priorizar aspectos parciais - econômicos, tecnológicos, ecológicos etc. - que parecem ser capazes de permanecer compreensíveis a partir de uma continuidade sem trauma com a ideia de nacional.

Essa continuidade, da qual falam noções como dependência, interdependência e imperialismo, está encobrindo a necessidade de submeter essas noções a uma profunda reformulação à luz das mudanças radicais que atravessam tanto a ideia de soberania quanto a de hegemonia. $O$ fato de ainda haver dependências e imperialismos hoje não significa que o cenário não tenha mudado, mas que os velhos tipos de vínculos são subsumidos e atravessados por novos, que não se permitem ser pensados a partir da transferência de categorias e noções como Estado, partido, sindicato, movimento social, território, tradição etc., isto é, sem que essas categorias e noções sejam previamente reformuladas. As condições de desigualdade entre nações, regiões e estados continuam e até pioram, mas não podem mais ser pensadas à margem do surgimento de redes e alianças que reorganizam e compreendem tanto as estruturas estatais quanto os regimes políticos e projetos nacionais. $\mathrm{O}$ desafio às ciências sociais, que Octavio Ianni aborda, torna-se ainda mais decisivo no campo da comunicação, cujas transformações desempenham um papel de protagonismo nos processos de globalização e na modernidade-mundo. E não apenas em termos da dimensão tecnológica, mas também no horizonte epistemológico a partir do qual os novos sentidos de comunicar se tornam visíveis.

\section{APROPRIAÇÃO CRÍTICA DA PESQUISA LATINO-AMERICANA}

Se o aporte do Brasil para a pesquisa de comunicação latino-americana tem sido tão fecundo, isso se deve, em grande medida, ao diálogo que a Intercom 
possibilitou. Com clara vocação latino-americanista desde sua criação, a Intercom vem dando corpo ao ritmo de sua consolidação como associação nacional e à institucionalização de seus contatos com os demais países da região: por meio de pesquisas comparadas, do intercâmbio ativo de pesquisadores e professores e da publicação de seus ciclos anuais de estudo e seu boletim, já convertido em Revista Brasileira de Ciências da Comunicação. Devemos adicionar, ainda, essas outras duas revistas, próximas à Intercom, que também mantêm um diálogo permanente com os pesquisadores latino-americanos: Comunicação \& Sociedade e Comunicação \& Política.

Explicitando esse desejo de diálogo, o Ciclo V, realizado em São Paulo, em 1982, tem como tema "Impasses e Desafios da Pesquisa em Comunicação", em um claro indicador da internacionalização, que se torna realidade, por um lado, nos trabalhos de pesquisadores brasileiros que refletem sobre as tendências da pesquisa de comunicação nos países metropolitanos e, de outro, na abertura à participação de pesquisadores de outros países, dos quais a maioria era latino-americana. A relevância dessa presença latino-americana será testemunhada no título da publicação que, com a coordenação de José Marques de Melo, reúne os trabalhos: Teoria e Pesquisa em Comunicação: Panorama Latino-Americano (Melo, 1983). A partir desse ciclo, a relação da Intercom com a pesquisa latino-americana se tornará cada vez mais forte. O Ciclo IX tem como tema central "Comunicação na América Latina: Desenvolvimento e Crise" e o Ciclo XII é dedicado às "Indústrias Culturais e os Desafios da Integração Latino-Americana".

Especialmente decisivo será o compromisso do Intercom na reconstituição da Asociación Latinoamericana de Investigadores de la Comunicación (Alaic), alcançada em 1989, dentro das sessões do Ciclo IX, realizado em Florianópolis. Retomando a proposta feita por vários ex-presidentes e membros da Alaic presentes no Congresso da Association Internationale des Études et Recherches sur l'Informationet et la Communication (Aieri) realizado no mesmo ano em Barcelona, Marques de Melo impulsiona a reconstituição da Alaic, que vinha passando por um longo período de crise, e assume sua presidência. Isso culminará na realização, em 1992, em São Paulo, do I Congresso Latino-Americano de Pesquisadores da Comunicação, no qual foi realizada uma avaliação das principais tendências de pesquisa nos anos 1980 e uma proposta de linhas prioritárias para os anos 1990 (Melo, 1992).

O diálogo com pesquisadores brasileiros da comunicação tornou-se particularmente fecundo nos últimos anos através dos debates introduzidos no Brasil, tanto sobre o sentido e o alcance da teoria e da pesquisa no ensino da comunicação quanto sobre a bagagem teórica com que a pesquisa é realizada 
e as estratégias metodológicas utilizadas. A esse respeito, me parecem particularmente relevantes as críticas elaboradas por Maria Immacolata Vassallo de Lopes $(1993,1994)$ a certas tendências culturalistas na investigação de processos de recepção que, ao substituir o conceito de classe social pelo da estratificação social, esquecem o sentido estrutural dos grupos sociais, retirando-os do caráter conflitivo que reveste a sua relação com as diversas formas de organização e expressão do poder. Reduzida à relação dos diversos grupos - de idade e de gênero - com o meio, e substituídas as instâncias de mediação estrutural por parte da família, da escola ou do bairro, a recepção acaba se convertendo em um processo circular, que dificilmente pode escapar do círculo que introduz a fragmentação dos consumidores proposta pelo mercado. A autora dessa crítica precisa também escreveu um dos poucos livros que na América Latina tiveram a coragem de assumir o desafio metodológico implícito pelos novos objetos e novas propostas de investigação (Lopes, 1990).

Mesmo se mais controversas, as críticas de José Marques de Melo aos modelos de ensino de comunicação (Melo, 1987, 1991) distanciados das demandas que vêm de um mercado de trabalho cada vez mais especializado e com uma proposta de perfil polivalente, que condenaria a maioria dos graduados ao desemprego ou ao campo do alternativo, também produziram um importante debate sobre o significado da teoria e da pesquisa no ensino de graduandos e pós-graduandos. Por um lado, é preciso repensar a presença puramente formal de cursos teóricos distanciados do trabalho criativo e produtor do comunicador e, por outro, revelar as armadilhas de um tipo de pesquisa cuja combinação de formalismo e denuncismo a torna incapaz de contribuir para o conhecimento das transformações pelas quais o campo da comunicação está passando. Esse debate, ao mesmo tempo, tornou imprescindível considerar formas de lidar com as tendências predominantemente mercadológicas no crescimento da pós-graduação, que, embora reflitam as demandas de especialização no campo laboral, ameaçam liquidar a presença das ciências sociais e qualquer caráter crítico dos estudos e da pesquisa acadêmica de comunicação. Esses traços são parte constitutiva dessa escola latino-americana de comunicação que o próprio Marques de Melo (1996) se propôs investigar e reivindicar.

Concluirei assumindo a voz dos meus colegas latino-americanos para reconhecer a presença decisiva da pesquisa brasileira no desenvolvimento de um pensamento latino-americano sobre a comunicação, que, ao mesmo tempo que nos permite uma compreensão mais profunda das peculiaridades e dinâmicas do nosso mundo, está nos possibilitando, no plano internacional, passar do ofício de informantes nativos para o de verdadeiros produtores de pensamento e de conhecimento. 


\section{REFERÊNCIAS}

Alves, L. R. (1987). A fábula forjando-se história. Aspectos da memória dos movimentos populares de ABC. In J. Martín-Barbero (Ed.), Comunicação e culturas populares na América Latina (pp. 230-237). Felafacs; G. Gili.

Austin, J. L. (1970). Quand dire, c'est faire. Threshold.

Beltrão, L. (1980). Folkcomunicação: A comunicação dos marginalizados. Cortez.

Beneyto, J. V. (Ed.). (1979). Alternativas populares a las comunicaciones de masa. CIS.

Busato, L., \& Caparelli, S. (1990). A novela vista de fora. Intercom: Revista Brasileira de Ciências da Comunicação, 13(62-63), 57-60.

Caldeira, T. P. R. (1984). A politica dos outros. Brasiliense.

Cardoso, R. (Org). (1986). A aventura antropológica. Paz e Terra.

Chaui, M. (1983). O nacional e o popular na cultura brasileira: Seminários. Brasiliense.

Chaui, M. (1990). Cultura e democracia. Cortez.

DaMatta, R. (1985). A casa e a rua: Espaço, cidadania, mulher e morte no Brasil. Brasiliense.

DaMatta, R. (1993). Conta de mentiroso. Rocco.

de Certeau, M. (1980). Linvention du quotidien. UGE.

Fadul, A. (1983). Sobre a recepção dos meios de comunicação de massa no Brasil. Orealc.

Fadul, A. (Ed.). (1993). Ficção seriada na TV: As telenovelas latino-americanas. ECA-USP.

Festa, R., \& Santoro, L. F. (1991). A terceira idade da TV: O local e o internacional. In A. Novaes (Org.), Rede imaginária: Televisão e democracia (pp. 179-195). Companhia das Letras.

Festa, R., \& Silva, C. E. L. (Orgs.). (1986). Comunicação popular e alternativa no Brasil. Paulinas.

Freire, P. (1969). Educación como práctica de la libertad. Nuevo Orden.

Freire, P. (1970). Pedagogía del oprimido. Tierra Nueva.

Gramsci, A. (1977). Cultura y literatura. Península.

Ianni, O. (1996). Teorías de la globalización. Siglo Veintiuno.

Leal, O. F. (1990). A leitura social da telenovela das oito. Vozes.

Lopes, M. I. V. (1988). O rádio dos pobres. Loyola.

Lopes, M. I. V. (1990). Pesquisa em comunicação: Formulação de um modelo metodológico. Loyola.

Lopes, M. I. V. (1993). Estratégias metodológicas da pesquisa de recepção. Intercom: Revista Brasileira de Comunicação, 16(2), 7-12. https://bit. ly/3eF691H 
Lopes, M. I. V. (1994). Recepção dos meios de comunicação: classes, poder, estrutura [Artigo apresentado]. VIII Encontro da Federación Latinoamericana de Facultades de Comunicación Social, Cali, Colômbia.

Magnani, J. G. C. (1984). Festa no pedaço: Cultura popular e lazer na cidade. Brasiliense.

Martín-Barbero, J. (1972). La palabra y la acción: Por una dialéctica de la liberación [Tese de doutorado não publicada]. Université Catholique de Louvain.

Melo, J. M. (Coord.). (1980). Comunicação e classes subalternas. Cortez.

Melo, J. M. (Coord.). (1981). Populismo e comunicação. Cortez; Intercom.

Melo, J. M. (Coord.). (1983). Teoria e pesquisa em comunicação: Panorama latino-americano. Cortez; Intercom; CNPq.

Melo, J. M. (Org.). (1987). Ensino de comunicação no Brasil: Impasses e desafios. ECA-USP.

Melo, J. M. (1991). Comunicação e modernidade: O ensino e a pesquisa nas escolas de comunicação. Loyola.

Melo, J. M. (Coord.). (1992). Comunicação latino-americana: Desafios da pesquisa para o século XXI. ALAIC/ECA-USP.

Melo, J. M. (Coord.). (1996). O pensamento latino-americano em comunicação [Número especial]. Comunicação \& Sociedade, (25).

Meyer, M. (1996). Folhetim: Uma história. Companhia das Letras.

Miceli, S. (1972). A noite da madrinha. Perspectiva.

Novaes, A. (1983). O nacional e o popular na cultura brasileira: Teatro. Brasiliense.

Ortiz, R. (1985). Cultura brasileira e identidade nacional. Brasiliense.

Ortiz, R. (1988). A moderna tradição brasileira: Cultura e indústria cultural. Brasiliense.

Ortiz, R. (1994). Mundialização e cultura. Brasiliense.

Ortiz, R. (1996). Otro territorio. Universidad Nacional de Quilmes.

Ortiz, R., Borelli, S. H. S., \& Ramos, J. M. O. (1988). Telenovela: História e produção. Brasiliense.

Piccini, M. (1987). Industrias culturales: Transversalidades y regímenes interdiscursivos. Diá-logos de la Comunicación, (17), 12-19.

Ramos, J. M. O. (1983). Cinema, estado e lutas culturais. Paz e Terra.

Rocha, E. P., Veiga, R. M., Quintella, M. M. D., Waitzfelder, D. A., \& Pereira, C. A. M. (1984). Testemunha ocular: Textos de antropologia social do quotidiano. Brasiliense.

Santos, M. (1993). Espaço, mundo globalizado, pós-modernidade. Margem, 2, 9-21.

Santos, M. (1995). La aceleración contemporánea: Tiempo, mundo y espacio-mundo. Revista Universidad del Valle, 10, 30-35. 
Schwarz, R. (1981). Ao vencedor as batatas. Duas Cidades.

Silva, C. E. L. (1980). Cultura de massa e cultura popular: Questões para um debate. In. J. M. Melo (Coord.), Comunicação e classes subalternas (pp. 41-48). Cortez.

Silva, C. E. L. (Coord.). (1982). Comunicação, hegemonia e contra-informação. Cortez; Intercom.

Silva, C. E. L. (1985). Muito além do Jardim Botânico: Um estudo sobre a audiência do Jornal Nacional entre trabalhadores. Summus.

Silva, C. E. L. (1986). As brechas da indústria cultural brasileira. In R. Festa \& C. E. L. da Silva (Orgs.), Comunicação popular e alternativa no Brasil (pp. 31-52). Paulinas.

Silva, C. E. L., Fadul, A., \& Santoro, L. F. (1982). Documento básico. In C. E. L. da Silva (Coord.), Comunicação, hegemonia e contra-informação (pp. 9-16). Cortez; Intercom.

Sodré, M. (1983). A verdade seduzida. Codecri.

Sousa, M. W. (1986). A rosa púrpura de cada dia: Trajetória de vida e cotidiano de receptores de telenovela [Tese de doutorado não publicada]. Universidade de São Paulo.

Sousa, M. W. (Org.). (1995). Sujeito, o lado oculto do receptor. Brasiliense; ECA-USP.

Squeff, E., \& Wisnik, J. (1983). O nacional e o popular na cultura brasileira: Música. Brasiliense.

Velho, G. (1981). Individualismo e cultura: Notas para uma antropologia da sociedade contemporânea. Zahar. 